\title{
Chinese Nationalism: Myths, Reality, and Security Implications
}

\author{
Symeon Giannakos* \\ Salve Regina University, Newport, Rhode Island \\ ^Corresponding author. Email: Symeon.giannakos@salve.edu
}

\begin{abstract}
China's most prominent dissident, the late Liu Xiaobo, criticized the Chinese Communist Party's efforts "to promote what he considered a toxic mixture of traditional culture and modern patriotism." $\mathrm{He}$ worried more about "a mentality of world domination" characterized by a "thuggish outlook." Quoted in Orville Schell and John Delury's (2013) book Wealth and Power, this statement reveals the culmination of some 150 years of nation-building, which now encapsulates what is probably the strongest and potentially most explosive primordial nationalism in the region since Imperial Japan. This article examines the sources of Chinese nationalism and gauges the extent to which Chinese nationalism contributes to cooperation or confrontation in China's foreign relations.
\end{abstract}

Keywords: nationalism; patriotism; statism; Chinese primordialism; Chinese territorial nationalism

\section{Introduction}

Academic publications on Chinese nationalism reveal a sense of optimism regarding its future outlook. They tend to project it in a positive light and argue that it could be or become constructive. They also tend to evaluate nationalism as a single-cause determinant of foreign policy, rather than contextualizing it within the anarchic international environment, critical Chinese security interests, and authoritarian domestic politics. Rather than asking what role Chinese nationalism will play if China is confronted by a critical international and/or domestic situation, publications typically evaluate Chinese nationalism in the same way one would evaluate a human personality in a social vacuum. They ask simple questions, like is nationalism aggressive or is it not? Is it confident or is it pragmatic? Even when Chinese nationalism is evaluated in the context of the international environment at specific critical junctures, the evaluation does not take into consideration the severity of the critical events. For example, evaluating Chinese nationalism in relation to the 1999 bombing of the Chinese embassy in Belgrade, one publication concludes "nationalism did play a role in the issue, but that role, if any, and if valid, is perhaps too limited and too satirical to be taken seriously by scholars interested in the big picture" (Shen 2004, 130). Tragic as the accidental bombing was, it was hardly of a critical nature and NATO immediately took responsibility for it. President Clinton publicly apologized for the bombing. He called it a "tragic mistake" and offered his condolences to the victims and to the Chinese leadership. Still, the Chinese leadership and press insisted the incident was deliberate. Considering NATO took responsibility for the mistake and President Clinton's public apology, the Chinese public outcry, including the stoning of the US embassy in China, and the worldwide demonstrations that took place were exaggerated and disproportionate. Similarly, it is perplexing that there was so much negative Chinese reaction against a student from China (a psychology and theater major) at the University of Maryland 
in May of 2017 for praising free speech in her commencement presentation. In any other state, this triviality would hardly be noteworthy. The exaggerated reaction, however, is noteworthy, and indicative of the nature of Chinese nationalism. How would the Chinese react to far more serious incidents and crises?

When publications do evaluate the role of Chinese nationalism in relation to such critical situations like territorial disputes in the East and South Seas, the conclusion is that Chinese nationalism will temper itself. Dixon $(2014,169)$ notes that "as the PRC becomes more comfortable in its role as a global power, references to historical grievances are likely to decline and the need for other countries to respect China will outweigh the desire to see past injustices corrected." Even if China becomes willing to accommodate its neighbors' views on the South Sea, will it be able to accommodate Taiwan's possible independence? What about Tibet, Xinjiang, and Inner Mongolia? Zhimin $(2005,36)$ concludes that "a positive form of nationalism has been constructed since the 1980s which is able to accommodate both the Chinese desire for national rejuvenation, and the general welfare of the world community." Maybe China will play a more constructive role in international institutions, but will it subordinate vital interests to getting along internationally? How would international institutions temper Chinese nationalism? Other publications justify their optimism on the basis of a wishful thinking that "nationalism in China is likely to decline over time as levels of urbanization and education continue to increase" (Tang and Darr 2012, 823).

The above conclusions come into sharp contrast with that of Zhao $(2013,536)$, who states that the Chinese government is increasingly more willing to be confrontational "against the Western powers and its neighbors, including the repeated use of paramilitary forces, economic sanctions, fishing and oil ventures and other intimidating means, to deal with territorial disputes in the South and East China Seas." In light of the deadly 1988 naval confrontation between China and Vietnam, a reader may wonder if even this conclusion should not be that China remains confrontational, rather than that it is more willing to become so. In an even more pessimistic publication, Tok $(2010,32)$ notes that "the persistent return to the same set of historical memories created a fairly consistent image of a nation in distress" which, as Hughes $(2011,601)$ points out, is reminiscent of pre-World War I Germany and Japan.

This paper agrees with Tok's and Hughes's conclusions and argues that it will only take one serious international and/or domestic crisis and a crisis mismanagement to show the true identity of Chinese nationalism. The paper, therefore, shows that Chinese nationalism is mostly primordial nationalism and, as such, it is inherently chauvinistic and can be easily used as justification and a mobilization tool for aggressive behavior. The reason primordial nationalism is inherently chauvinistic is because it denies it is actually constructed, albeit on primordial grounds. It is, therefore, the self-denial of primordial nationalism that makes it more aggressive, just as self-denial makes alcoholism more dangerous. The analysis, therefore, shows how Chinese nationalism has been constructed on primordial grounds and demonstrates its self-denial and inherent aggressiveness.

\section{Maoism, Statism, Patriotism, and Nationalism}

In his monumental work Imagined Communities, Benedict Anderson $(1999,2)$ reveals a fundamental truth about socialism and nationalism. Recalling Eric Hobsbawm, he restates that Marxist states tend to become nationalist, not only in form but in substance. Quoting him directly, he writes that "the theory of nationalism represents Marxism's great historical failure" (3). There is little that can be added to this statement, except to say that the same applies to Maoism, which, as a political ideology, was both deadly and a miserable failure. Yet the seemingly endless daily stream of visitors to Mao's mausoleum or Memorial Hall in Tiananmen Square suggests that the idea that Maoism was a failure might be far from the truth. Have the millions of Chinese visitors who reverently paraded there since 1977 in front of the dead chairman done so out of respect for Maoism? Despite the fact that the Chinese economic system has parted ways with Mao, the stream of visitors has been constant. Comparing Mao's visitors to those of Lenin, 
Wikipedia tells us that more than 10 million people visited Lenin's mausoleum from 1924 to 1972 , but the line is awfully short these days. Why is Mao still attracting visitors, then? The answer must be that where Lenin failed to inspire patriotism, Mao did create Chinese patriotism and set the stage for the creation of Chinese nationalism and the nation.

Regarding the term nation, Anderson notes "it has been proven notoriously difficult to define, let alone to analyze" $(1999,3)$. He goes on to argue that there are three paradoxes that irritate theorists of nationalism. The first paradox relates to the "objective modernity of nations to the historian's eye vs. their subjective antiquity in the eyes of nationalists" (5). It is rare for most nationalists to admit that their nation is just a modern creation, but they typically spare no effort to convince all of the ancient existence of their nation. Nationalists of this persuasion, and more often than not national historians, may be referred to as primordialists or those who are convinced that their nation has existed since before recorded time.

The second Anderson paradox refers to the fact that every person has a nationality or what he refers to as the "formal universality of nationality" versus the "irremediable particularity of its concrete manifestations" $(1999,5)$. In other words, he argues that each nationality thinks of itself as unique. Here again, primordial nationalists are convinced that not only has their nation existed since before recorded history, but its existence has been characterized by cultural characteristics not found in any other group formation. A trivial analogy to illustrate this paradox is to refer to the custom to describe each baby as the prettiest baby in the whole wide world and there has never been a prettiest baby ever before and will never be another one ever after. When one challenges this nationalist attitude on the grounds that cultures might be different over long distances, but fairly similar between proximate ones, typically one is confronted by an irremediable strong dose of denial and a strong confrontational tone. It is equally pointless to argue that what one considers a monolithic culture is, in fact, not so.

Anderson's third paradox refers to the "political power of nationalisms vs. their philosophical poverty and even incoherence" $(1999,5)$. In fact, when one asks nationalists or historians of a specific nationalism to list the specific qualities of a specific nation, they are incapable of providing any specific answer. If pressed, they simply refer to generalizations, anecdotal truisms, and mythological pasts and futures that never were and never will be. Primordial nationalism is all form and little substance. It is reduced to specific trivial characteristics that only some of the people follow some of the time and never exclusively so.

In contrast to primordial nationalism, constructed nationalism emphasizes the legal rights and obligations of all citizens. Constructed nationalism is mostly substance and very little form. In constructed nationalism, a person's identity as a citizen and a person's identity as a national are meshed into a comfortable substance. Where primordial nationalism denies that it is also constructed, constructed nationalism admits it easily. One, therefore, is less likely to offend a constructed nationalist or one who knows her identity to be a product of modernity. A constructed nationalist realizes that her identity is just one among many and that it is possible for a nationalist to subordinate reason to passion in relation to vital state interests. This realization usually negates fanaticism. Does this make primordial nationalism more aggressive than constructed nationalism? The answer is yes, but only because that which produces primordial nationalism is more aggressive than that which produces constructed nationalism.

Based on the above, therefore, to properly evaluate Chinese nationalism, one needs not only to know whether Chinese nationalism is primordial or constructed, but also to understand the process which produces and maintains it. At the end of the day, nationalism is nothing but a tool. In itself, it can neither kill nor cure, but it depends on how it is being formed and used by both governments and people. Nationalism is impotent until it is connected to specific interests of state and national security. The same also applies to patriotism.

In contrast to nationalism, the term patriotism is easy to define and explain. Walker Connor (2002) separates nationalism from patriotism by noting that where patriotism denotes loyalty to the state, nationalism denotes loyalty to the nation. In this regard, Lenin was a Soviet patriot, but 
not a Soviet nationalist; there was a Soviet state, but not a Soviet nation. If one wanted to know what the Soviet state was, one would look at a map and see it highlighted in a specific color to distinguish it from other states each highlighted by a different color. If one wanted an in-depth understanding of the Soviet state, one would read its history, its political institutions, its government and political leadership, its political party, and its politics and policies. Similar to the Soviet example, today one is a British patriot if loyal to the United Kingdom of England, Scotland, Wales, and Northern Ireland, but one is not a British nationalist because a British nation was never constructed. If Mao's ideology is no longer appealing, are people still visiting him because he was a patriot, a nationalist, or both?

Looking at a translated copy of Mao's Little Red Book (Mao Zedong 1966) one sees references to patriotism, but not to nationalism. For example, in trying to determine the relation between patriotism and internationalism, Mao does not state what patriotism is, but that "there is 'patriotism' of the Japanese aggressor and patriotism of Hitler, and there is our patriotism" (283). Did he, by "our," mean all the people in China, only the Han people in China (but not the Manchu or anyone of the some 56 other recognized group entities)? Also, did he consider a person loyal to Hitler to be a German patriot as well? If one was loyal to Hitler or to the Japanese emperor, was that person also a German patriot or a Japanese patriot, respectively? If one should be both loyal and a patriot, then what were those who were disloyal to the Japanese emperor or Hitler but loyal to Japan or Germany? Was Mao trying to say that "theirs" was a primordial nationalism, but the Chinese one is not? Clearly Mao did not think things through, but he still receives a great number of visitors just the same. One cannot help wondering whether his visitors themselves are patriots, nationalists, or both.

Since patriotism and nationalism play important roles in a country's foreign policy (they are indispensable tools in mobilizing and justifying), to appreciate the parameters of a given state's policy, it is critical that one understands what both the government and the people of that country think of state, patriotism, nation, and nationalism. To understand the role nationalism plays in Chinese foreign (and domestic) policy, one should start by asking whether China itself is a new state or whether it has existed since before recorded history? What is the Chinese nation and what is Chinese nationalism like? If there is such a thing as a Chinese nation, did it exist since before the beginning of recorded history or is it a recent creation? Is it primordial or constructed? Who considers himself or herself part of the nation and who does not? Who is a Chinese patriot and who is a Chinese nationalist? Do they admit their identities to be constructed and modern or primordial and ancient? Is Chinese nationalism more about form or more about substance? To be able to answer these questions, one needs to determine the process and content of nationalism in China and what the general view in the country is about the existence of China, the Chinese nation, and the ingredients or characteristics of Chinese nationalism. Once this is done, one can properly evaluate both the form and substance of Chinese nationalism.

\section{Linguistic Continuity}

It would be a futile exercise to try to study Chinese nationalism without an appreciation for the corresponding Chinese terms for state, patriotism, nation, and nationalism. This is a difficult task for those who know the language and a daunting one for those who do not know it. All the same, the development of the language itself reveals the primordial or constructed form of nationalism. For example, if one wants to rely on Google's translator to translate English into Chinese, Google offers two options: traditional and simplified. Naturally, one wonders about the differences between the two. Google translates an English word into the same sound for both the traditional and the simplified version. The script, however, differs depending on the word translated. What this reveals about the Chinese language is that the script changed at some point in history. John Fairbank, the American Thucydides of Chinese history, notes that "Chinese writing that enabled Chinese, Japanese, Koreans and Vietnamese scholars to communicate with one another was a 
great common channel of contact among those that knew it. Merchants speaking the mutually unintelligible languages of Canton, Shanghai, and Shansi provinces could get along fine, in writing" $(1987,67)$. He writes that as many as $45 \%$ of men and maybe $2 \%$ of women enjoyed a degree of functional literacy. This suggests that not only did the script change at some time in history, but also that different people spoke different languages within the imperial domain and the only way to communicate across the linguistic divide was to use the official script and dialect, which most people did not know. The familiar analogy to the reader here may be Latin. Being the official language of many political orders in Europe, it facilitated communication among elites across Europe, but it was not understandable to common people. Similarly, the official script of the Ottoman Empire was Arabic, but the vast majority of its imperial subjects could not read it.

In the imperial domain of the heavenly kingdom, the few who could read the traditional script could understand it, but it was unintelligible for the vast majority of peasants who were illiterate. In old China, Fairbank writes,

the real divider was the classical learning-not only in the many thousand complex characters but also the several layers of meaning that some characters had accumulated over the centuries and, finally, the hard-won knowledge of text and commentaries. This "literacy in the classics" was what set the classically trained literatus a world apart from the illiterate or barely literate commoners. ... Would-be officials spoke the lingua franca of the Peking dialect kuan-hua (official speech). Conversations replete with classical quotations and allusions, in terms that a peasant even if literate could not understand, were the hallmark of the literati. The separation was reinforced by the ironbound tradition that men of learning did not use their muscles, even their hands, except for calligraphy. The bifurcation of Chinese culture into classically literate and comparatively illiterate compartments buttressed the ruling-class position. The examinations were a ritual that preserved and rationalized this great social division. (1987, 67-68)

By "examinations," Fairbank means the imperial examinations which one had to pass in order to become part of the imperial bureaucracy. It emphasized memorization and conformity and was a great tool deployed by the imperial order to coopt the elites of the territorial domain. In essence, the imperial examination was the mental gladiatorship by which the survivors could become citizens from slaves. An imperial subject who passed the examination at each level would be appointed to the corresponding county, district, provincial, or palace bureaucracy. It was an institutionalized feudal system that provided a false sense of upward mobility when, in reality, only a few children of wealthy peasants were likely to pass it all the way to the fourth level. Furthermore, in the absence of concrete data, the extent to which it produced functional literacy must be questioned. A foreign language is being taught in every high school and college in the United States, but how many students really become literate in it?

Fairbank notes that imperial provinces were the size of European countries and were the most intelligible units of discourse, with which individuals still identified themselves. Provinces were defined by culture and history, set apart by their dialects (in southeast China really local languages), their cuisines, their economic and strategic geography, and their common bonds of folklore and tradition. Patriotism began at home and the gentry elite of New China organized most easily in the provincial metropolis, which had usually been the center of the old provincial examinations, the training of new armies, and the contact with foreign ways that stimulated change. Provincialism could thus express the broad sentiment of nationalism in the most effective way $(1987,159-160)$.

In the political context described by Fairbank above, it would be absurd to even contemplate the meaning of terms like Chinese nation, nationalism, and patriotism. It was not really until after World War I that the meaning of such terms started taking hold following the vernacularization of the official language. In fact, he points out, it was returning scholars that initiated 
the language reform process. He credits Hu Shih who, after attending Cornell and Columbia for seven years, returned "with a conviction that written Chinese must change to a vernacular style, using the vocabulary of speech. Europeans had done this at the time of the Renaissance, breaking away from Latin and developing written Italian, French, German, and English as national languages" (1987, 189). In fact, this process was still continued in the Austro-Hungarian and Ottoman Empires at that same time. Political elites and intellectuals in these two imperial orders were still engaging in the process of adopting vernacular languages as the official languages of their would-be states. Turkey, for example, did not switch from Arabic script to Latin script until 1928, six years after independence, and only after the Soviet republics of Central Asia did so.

The problem with the Chinese script was that the classical script used single characters to denote meaning the same way that words are used in Latin. Instead of a word, the Chinese language uses a depiction or a picture of sorts. Over the years many characters started to seem similar to one another, because they were as hard to distinguish as identical twins might be. In the English language, one can demonstrate this problem through the pronunciation of the words hole and whole and the words piece and peace. For the symbols in Chinese that appeared nearly the same, a second symbol was added to make the differentiation obvious, like no-war peace and pie piece.

Together with the journalist Ch'en Tu-hsiu, Hu Shih started promoting the two-character script and by 1920 (15 years after the abolition of the imperial examination system) the Ministry of Education decreed its use in textbooks (Fairbank 1987, 189-190). It was not till 1928 that mass education was initialized with the specific purpose of promoting and safeguarding the interest of the state, which at the time was dysfunctional, ineffective, disorganized, primitive, and hardly existent in practice. Under the circumstances, mass education was not in place either and the creation of a new script did not reach the peasants who remained illiterate, without any degree of homogenous identity or sense of patriotism.

As early as 1942, Mao initiated a rectification campaign that stressed patriotic themes. The Chinese Communist Party's (CCP) propagandists were dispatched to villages to train the peasant masses and "instill among the people a will to resist Japan and support their own armies" (Shaller $2015,78)$. By 1949 , the educational system barely produced some 185,000 college graduates, or $0.1 \%$ of 400 million people. In fact, most of them were the result of liberal arts education offered by Christian colleges which had been experimenting with mass education in the villages for quite some time (Fairbank 1987, 291). It was not until after 1949 that mass education expanded. Mass education was the work of the CCP, which even as late as 1978 only managed to increase literacy rates to a maximum of $66 \%$ (Fairbank 1987, 284). Still, perhaps the biggest success of Mao's revolution was to universalize both the script and the official language based on the Peking dialect. This has made it possible for people from different linguistic backgrounds to be able to communicate with each other through the written script the way two children from two different countries recognize a picture of a chicken regardless of what the name for chicken is in their language.

To conclude, then: Mao himself did not make use of the terms nation and nationalism and before the universalization of the script and the initiation of compulsory mass education, the official language was not understood by peasants. The peasants could not read the official script and they spoke different languages. The current script of the Chinese language, therefore, is not even 100 years old, and the official language did not have words for patriotism, nation, or nationalism. It is then in the context of the CCP finishing the process of mass education and the way mass education refers to the domestic and international environment that terms like patriotism, nationalism, state, and nation acquired meaning. Since different environments produce different meanings for the same words, one must look at the content of nationalism produced by public mass education to capture its meaning. As Ernest Gellner (1983) authoritatively wrote, the state controls education and education produces the nation. Each state defines the terms and, though selective use of empirical evidence, produces the content responsible for 
creating Anderson's imagined community. The process of constructing the nation, then, began with the linguistic homogenization of highly diverse human populations. Once diversity was eliminated, Chinese nationalism would subsequently deny its pre-national existence.

\section{State, Patriotism, and Nationalism}

In his book Never Forget National Humiliation: Historical Memory in Chinese Politics and Foreign Relations, Zheng Wang (2012) demonstrates how the Chinese state today uses history selectively to create attitudes and perceptions regarding the international system, the state, the nation, and the government. It should be pointed out at the outset that the use of the phrase "national humiliation" denotes a primordial attitude that the nation precedes the state. One should legitimately ask at this point, was the Opium War and the defeat by the Japanese Empire in Manchuria in 1895 a national humiliation or just the humiliation of a political order that was fast becoming obsolete? What was the people's perception of that political order? Did the phrase become popular during the nationalization process, as it certainly was once it was completed?

Wang notes that "for the ancient Chinese . . . China is called Zhong Guo," which means "middle kingdom" $(2012,42)$. Yet other sources translate Zhong to mean "center," while the meaning of the word Guo has changed to also mean "nation." The same sources also note that "China is also called Zhonghua, and in ancient times hua meant 'splendid' and 'prosperous' and could also be used to refer to a beautiful dress or rich ornament." He notes that the "Ancient Chinese believed their group was the chosen people who lived in a sacred land in the center of the world. They were proud of their own beautiful dress and high culture" (Wang 2012, 43). While it is doubtful that the peasants wore splendid dresses and were aware of high culture, other sources translate the word hua to mean "speech." Distinguishing between historical facts and historical myth is impossible.

In any case, the word for nation today has the same root as the word for kingdom. It is Guójiā. The word for nationality is Guóji; the word for nationalism is Mínzú zhǔyi; and the word for people is ren while the word for peoples is renmin. The word for state is Zhou; for Chinese state is Zhōngguó guójiā (or Chinese kingdom/nation); and for patriotism is Àiguó zhǔyì while patriot is Àiguó zhě. The word for Chinese nation is either Zhōngguó mínzú or Huaxia minzu, depending on who is writing and who is translating. Like changes in the script, the meanings of words also changed along with the domestic and the international context. The word kingdom became nation the word subjects became citizens. New meanings of old words are taken to be old meanings of old words.

There is no clear evidence demonstrating where the words China or Chinese came from. The tendency is for primordial historians to argue that it came from the Qin dynasty in around 200 $\mathrm{BCE}$ and for modernists to argue that it came from the Qing dynasty in 1644-1911. What is clear is that the Chinese do not use that word to describe themselves even today; they call themselves Zhōngwén and China is still called Zhōngguó. Yet people used to use completely different terms to refer to what we call "China" today. Similarly, the idea that the Chinese nation was formed thousands of years ago is not supported by any concrete evidence. Early attempts at classifications visualized all the people of Asia to be one race that included the Japanese along with the Koreans and Vietnamese. The first flag of the new republic, created in 1912 at the end of the Qing dynasty, consisted "of five differently colored stripes symbolizing a unified state of five 'races' (Han, Manchu, Mongol, Tibetan, and Muslim)" (Nathan and Ross 1977, 34). The Han majority itself was "a mix of people with a broad spectrum of physical characteristics, speaking eight major dialects and many minor dialects as different from one another as Italian and French" (Nathan and Ross 1977, 31). What is now west and northwest China was "dominated by a mosaic of peoples whose cultures were more closely linked to India, Persia, and Turkey than to coastal China" (Nathan and Ross 1977, 193). In this context, the primordial cultural interpretation which argues that China was a unique cultural entity comprising a cultural community 
under the umbrella of cultural nationalism all tied together by Confucian ideology is a historical myth. Suisheng Zhao, quoting historian Liang Shuming from the 1930s, points out that "traditional Chinese thinking was lacking in the concept of nation (guojia guannian). People loved to talk about the land under heaven (tianxia) showing ... the development of China in history was a universe not a nation" (Zhao 2004, 41).

Under the concept of universalism, anyone could become a subject of the emperor or a son of heaven. The emperor's domain was the universe beyond which lived the barbarians, outside the reach of the imperial bureaucracy, always advocating traditional values and always relying on a balance of power among the palace bureaucracy, the provincial bureaucracies, and the peasants. The aim was to maintain imperial order, collect taxes, avoid infighting among provincial rulers, prevent rebellions by the peasants, and maintain harmony on the basis of traditional values under the heavens and though out the center of the universe. As mentioned above, under the imperial umbrella, multiculturalism and multilingualism prevailed and each locality had its own set of deities they worshipped. In this regard, the imperial entity was not unlike the Byzantine Empire - with its universal Christian culture and religion, multilingualism and multi-dialectism, and official Greek language incomprehensible to the vast majority of subjects - always expanding and contrasting, always experiencing domestic turmoil among warlords themselves (vying for territorial expansion and the right to collect taxes under the farm taxing system) or between prominent warlords and the emperor in an attempt to become emperors themselves. Far from being unique, China was a typical imperial order. This reality, therefore, contradicts the primordial claim of uniqueness or what Anderson refers to as an "irremediable particularism."

A comparison between the imperial order of the heavenly kingdom and the Ottoman Empire also supports the idea that imperial China was not unique but typical. Both the Ottomans and the Manchus were minorities in their imperial domain. Both empires were gradually exposed to the expansion of the state system. At the time, the Ottomans were fighting for their lives against the Russians in the Crimean War and the Russo-Turkish War of the 1870s; and the Manchus were fighting the Opium Wars against the British. Just as the Ottomans were defeated by the Russian Empire, so were the Manchus defeated by Imperial Japan. In 1911, the Ottomans suffered a humiliating defeat by the Italians and in the same year the Empress of China, Dowager Xixi, signed an official letter of abdication. For all intents and purposes, the Ottoman Empire was also done with and easily defeated by the combined forces of Greece, Serbia, and Bulgaria in 1912. Far from being unique, the Center Kingdom went through the same modernization and system pressures as other imperial orders. As is evident from the previous section, when Mao came to power in 1949, there was hardly any widespread notion of nationalism.

In the above context, there are two important points that need to be made to understand the content of Chinese nationalism today. One has to do with the Han Chinese, or the majority Chinese, and the other has to do with the state, the CCP, and its connection to the terms patriotism and nationalism. There is much historical talk today about the fact that the majority Han Chinese were ruled by the minority Manchus during the Qing period. But in the context of universalism, these identities were not there yet. "The creation of an ethnic Han identity," writes Suisheng Zhao, "goes back only to the nineteenth century. The term 'Han' emerged in the context of a discussion framed by Social Darwinism when scholars like Liang Qichao responded to the European notion of race by claiming that the yellow race was dominant in the Han people who "were the initiators of civilization and had civilized the whole of Asia" (Zhao 2004, 21-22).

In fact, Liang is considered to be the godfather of Chinese nationalism. Born in a village outside Canton, Liang was supported by his family in receiving universal education and eventually "attended the Sea of Learning Academy, where he was inducted even deeper into the rigors of nearly useless Confucian scholarship and classical philosophy" (Schell and Delury 2013, 93). By the age of 16, he passed the provincial imperial examination level, but he subsequently failed twice to pass the examination at the imperial level. Instead, he became a proponent of constitutional monarchy, edited an anti-establishment publication called the New Citizen, and 
advocated for the destruction of the old system and its replacement with a new one. The new citizen, according to Liang, "would require the complete destruction of the baggage of China's traditional value system. The old edifice had to be razed to the ground, or else nothing new would ever be able to replace it" (Schell and Delury 2013, 104). He argued that the core of the problem of backwardness in China was the lack of citizen rights and responsibilities, consciousness, and "a crippling absence of national consciousness Guojia sixiang" (106). Subsequently and after the Empress's abdication, Liang came to the conclusion that "only despotism could make China ready for democracy" (107). Once again, for the initiators of the nationalization process, there was no Chinese nation in place. The term sovereignty (zhuquan) did not appear in the lexicon until the mid-19th century (Tok 2010, 26).

Another revelation that came to Liang and other revolutionaries like Sun Yat-Sen, especially after the imperial abdication, was that Han nationalism would not be a viable idea. The majority of land owned by the emperor and added under the Qing dynasty was in areas not inhabited by those now referred to as Han Chinese. For that reason, Sun promoted the creation of a state in which all different groups would coexist in harmony under the umbrella of Han culture. He promoted the idea that race and culture would be the unifying element of the nation and "imagined the country's struggle against imperialism as a form of resistance against the threat of miezhong, 'racial extinction,' in which the 'white' race would triumph over and obliterate the 'yellow' race" (Schell and Delury 2013, 101). It is also clear that by this time, the construction of nationalism by the intelligentsia started on primordial bases emphasizing biology and uniqueness of culture.

Zhao notes that "the Provisional Constitution of the Republic of China written in 1912, specifically identified Mongolia, Tibet, and Qinghai as integral parts of the nation [sic] even though these territories were only recent additions to the Qing empire" $(2004,22)$. The Eastern Turkestan Republic was not administratively integrated into China as a province till 1884 to subsequently become the Xinjiang (new frontier) province (Nathan and Ross 1997, 196).

In the state-making process, Sun's Guomindang Guomin dang (national citizen's party; KMT) nationalist program "called for the recovery of China's 'lost territories,' including Hong Kong, Macao, and the Ryukyu Islands" (Zhao 2004, 84). A great number of politicians and people, however, did not share Sun's patriotic vision. Echoing Fairbank earlier in the analysis, Zhao notes that "they were deeply divided by different regional identities and identities along different class lines" (84). The KMT, he concludes, was never able to build a coherent Chinese nation that transcended these regional and class divisions." In retrospect, one can see that without a mass public education system, the Guomindang plan was simply nothing more than wishful thinking. Fairbank writes that the Guomindang "did not get hold of China's major problem even in the restricted area in which it operated, and so its village program remained quite limited. ... The theme of taking literacy to the common man and inducting him into the higher society of modern times remained to be pursued by the young CCP" $(1983,193)$.

The nationalists envisioned the state at the maximum territorial domain in existence under the Qing dynasty and their objective was to reestablish territorial sovereignty over that domain against emerging provincial nationalism and external pressures. It is safe to assume that they would have never succeeded. The biggest problem the Guomindang faced was its attempt to recreate what time and circumstances had proved unworkable. Due to external and internal pressures, imperial China had come apart at the seams and the Guomindang's remedy was all form and no substance. The Qing Emperors, relying on the imperial examination, which also served as the base for culturalism, had maintained a fragile balance between the top of the pyramid and the bottom of the pyramid by managing the middle or the provincial bureaucracy. The emperor made certain that taxation in the provinces was not so exorbitant as to cause rebellion. The collapse of the examination system in 1905 and the abdication of the Empire in 1911 left the warlords free to torment the peasants. Based on landlord support, the Goumindang was itself an imperial, corrupt, ineffective, and inefficient organization, incapable of creating 
either state or nation and impotent against the Japanese, even with outside support. They were a bunch of urbanite megalomaniacs oblivious to the needs of the vast peasant majority. Their moral and political bankruptcy, reminiscent of the imperial moral and political bankruptcy of the Qing, gave the CCP the political advantage and eventually the military advantage. It is fair to state, then, that during the Republic Period or the period between the abdication of the empress and the Communist takeover, there was neither a state nor a nation in place. In fact, it is accurate to state that we witnessed the transformation from universalism to feudal fragmentation and the potential for the creation of multiple states.

Having built strong political support by responding to the peasants' needs, such as lowering taxes and undertaking land reforms against the powerful landlords, but without alienating the middle peasantry, the Maoists defeated the Guomindang in 1949 and forced them to flee to Taiwan. In fact, the CCP did not nationalize the land until well after it was in firm control of the country in the 1950s. By that time, Mao had abandoned Lenin's nationalist policy of accommodating and even creating different nationalities and opted for a unitary system. Zhao quotes Zhou Enlai in 1950, saying "For thousands of years, ethnic groups were not united and even hated each other. This was the result of the oppressive policies of the reactionary rulers, particularly the imperialists and their Chinese running dogs in recent decades. ... Today, not only have all ethnic groups been united, but love for the motherlands has also been growing in their hearts" (2004, 177-178). Quoting Mao in 1956, he notes, "when we say China has vast land, rich resources and a huge population, what that actually means is that the Han nationality has a huge population and ethnic minorities have a vast land and rich resources" (Zhao 2004, 178). Territorial sovereignty, therefore, became the essence of Chinese patriotism, under the auspices of the CCP's rule on the basis of Lenin's democratic centralism platform: strong leadership, party discipline, and political centralization through which the army is subordinate to the party and the state. The year 1949 was not just the year of the victory of the CCP against the Guomindang, but the creation of the Chinese state. Gradually, what came to happen is that instead of Communism exploiting nationalism, nationalism came to exploit Communism.

Staring right away in 1949, the CCP "dismantled the liberal-arts programs inherited from the Christian colleges and national universities" (Fairbank 1983, 290). In 1952, it set up a Ministry of Higher Education and started to standardize "teaching plans, materials, and textbooks, so that training programs in all specialties were prescribed from the center" (290). A required component in the curriculum was Marxism/Maoism, but as the economy failed to improve, the CCP gradually turned from futile ideological indoctrination to more pragmatic patriotic education in the 1970s. By 1993, the State Education Commission announced a new

Program for China's Education Reform and Development. Accordingly, the CCP Central Propaganda Department, the State Education Commission, the Ministry of Broadcast, Film, and Television, and the Ministry of Culture jointly issued a circular on Carrying out Patriotic Education in Primary and Secondary Schools throughout the country by Film and Television (Zhao 2004, 218).

The CCP reintroduced the myth of the glorious past and modern suffering, projecting itself as the savior of the Chinese mosaic. Basically, according to Zhao, the content of patriotic education focuses on four unique Chinese themes:

1. China is a beautiful and resource rich, but overpopulated country, which despite this burden has achieved great success. However, the population burden has seriously limited social progress and economic development.

2. China has a long history, flourishing culture, and glorious traditions. ... [It is] a unique place with a great civilization ... and numerous patriotic sacrifices. 
3. Many tried to save China after the Opium War and failed. The CCP finally lead the Chinese people to final victory. Only the CCP can take the leadership role in revitalizing the Chinese nation.

4. China is still in the primary stage of socialism. (2004, 224-225)

Explicit in the content above is the primordial notion that China, or the state, has a long history and that the CCP revitalized the Chinese nation. This is a prime example of Anderson's observation by which objective modernity is negated by subjective antiquity. As the analysis demonstrates, neither the Chinese state nor the Chinese nation was in place before 1949. It is this subjective antiquity in the context of modernity that Liu Xiaobo finds disturbingly toxic. It is toxic because, apart from providing the CCP with undeserved legitimacy, it also creates a mood of victimization in the hands of "foreign devils." History is subjectively simplified with a good versus evil mentality that allows for little space for compromise. Subjective antiquity makes it impossible to accept the contingency that Taiwan or the South Sea are not China.

Patriotic education, therefore, is centered on creating a patriotic aiguo sentiment and promoting aiguo zhui (patriotism) or loving and supporting Greater China, which is indistinguishable from the state and the CCP. Schoolchildren learn not about human history in general, but "about treaty ports and concessions (foreign governed areas of Chinese cities), foreign leaseholds and spheres of interest, extraterritoriality, by which foreigners in China charged with crimes were judged under foreign laws by foreign judges" (Nathan and Ross 1997, 34). It is this historical subjectivity that leads to an inferiority complex that fuels the desire for territorial and economic greatness or the return to the glorious past.

Beyond formal education, the party's nationalization process extends to the broader public through the media. The CCP's propaganda system shapes public opinion by "creating a general frame and allowing scholars and government-controlled media to fill in the details" (Hao 2013, 133). The CCP influences the media and the media create public opinion. In 2011, for example, right before US Vice President Biden's visit, a media outlet conducted an online questionnaire soliciting the public's input on what they would like to tell him. The top five questions and comments were: "do not intervene in the South China Sea issue, stop selling arms to Taiwan, cut the fiscal deficit, abrogate the export restrictions of high-tech products to China, and stop supporting the Dalai group and other ethnic division forces" (Hao 2013, 132). The Englishlanguage mouthpiece of the CPP in China, China Daily, is printed in nine cities in the US (Lautz $2013,217)$. The key factors contributing to the periodic reemergence of aggressive actions about territorial disputes, notes Kleinsteiber (2013), "are the domestic political rhetoric, rising nationalism through domestic political manipulation, and the use of narrative of irredentism and historical animosities" (18). Chinese nationalism is fueled by created images of national humiliation and chauvinistic pride in China's glorious past in which it still suffered at the hands of foreigners. The most important word in this process is not China, which does not even exist in the vocabulary, but aiguo, which is the heart of territorial sovereignty, party dominance, and political monopoly.

The irony is that the people, the Han people, based on the success of patriotic education and the media, have become more patriotic than the CCP itself. Instead of worrying that the CCP will be able to mobilize the people on vital national interests like that of Tibet or the South Sea, one should worry about the people themselves, the Han Chinese, now predominantly living in some $36 \%$ of the country's territory, compelling the CCP to take a stand against foreign and domestic usurpations. The "people" would be willing to cooperate but only to the extent that their fixed views on territory and resources allow it. These are not negotiable as they are at the heart of the sentiment of what it means to be Chinese. The political system is not just a people's dictatorship, but the Han Chinese people's dictatorship. Mao built it along with the Chinese state and that is the only reason visitors still revere him. He succeeded where Empress Dowager Xixi, Liang Qichao, Sun Yan-Sen, Chiang Kai-Shek, and Chen Duxiu all failed and miserably so. The South 
China Sea is a big issue, but so is the $64 \%$ of the territory of the state that was only recently incorporated to it. How many in China really care to know that the first unified imperial order, created by the Qin, only occupied a quarter of the current territory of the People's Republic? (Nathan and Ross 1997, 20). It was only in the 1800s that the new territories were added and have since been colonized by Han Chinese. National humiliation is a two-sided sword and at the end of the day; more Chinese have died at the hands of Chinese than at the hands of nonChinese. The book on domestic humiliation has not been written yet while discontents like Liu Xiaobo die away without even becoming known inside the borders of their country.

Territorial nationalism, clearly the most prevalent form of constructed primordial nationalism, will not diminish until there is a major revamp of the educational content to make it less chauvinistic, more international, and more open to constructed compromise based on reciprocity. But to do so, the CCP must be willing to risk becoming obsolete. It took a lot of bloodshed for the Qing to stay in power and to give up power, it has taken even more bloodshed for the CCP to stay in power, and, unfortunately, will take even more for it to give up power.

\section{Conclusion}

Despite the collapse of the Empire, the Chinese state became imperial all the same. The political system was not modernized but retained the same bureaucratic structure and qualities. There has been partial economic modernization, but as in the case of Japan, that is bound to reach a ceiling. Unlike China, Japan achieved political modernization. The Chinese political system is still primitive and imperial. Because discussing the political system is not permitted, discussion focuses on culture, ancient and modern, which then contributes to the deepening of primordialism. Primordialism has become pervasive and it will be impossible to reverse without risking the viability of the political system and the state itself. Questioning the political system is the same as questioning China itself. Some do, but they pay a heavy price. Emphasis on primordial nationalism tends to explain international relations though a second-image explanation or though domestic politics of mythological victimization and suffering. This makes realistic evaluation of international affairs difficult and undermines the prospect of creative compromises. As Samuel Huntington wrote in the 1960s, praetorianism is incapable of initiating or achieving political development. The final chapter on Chinese nationalism has not yet been written. The state and the nation are still being developed, but it is hard to see how that development will not include violence of unthinkable proportions. The first step in preventing this is to start internationalizing the curriculum, eliminate subjective antiquity and particularism, and replace the philosophical poverty of the national discourse with a political discourse centering on not just economic development, but political development as well.

\section{References}

Anderson, Benedict. 1999. Imagined Communities: Reflections on the Origin and Spread of Nationalism. New York: Verso. Gellner, Ernest. 1983. Nations and Nationalism. Ithaca, NY: Cornell University Press.

Fairbank, John King. 1987. The Great Chinese Revolution, 1800-1985. New York: Harper and Row.

Connor, Walker. 2002. “A Primer for Analyzing Ethnonational Conflict." In Ethnic Conflict: Religion Identity and Politics, edited by Symeon Giannakos, 21-42. Athens: Ohio University Press.

Dixon, Jonathan. 2014. "East China Sea or South China Sea, They Are All China's Seas: Comparing Nationalism among China's Maritime Irredentist Claims.” Nationalities Papers 42 (6): 1053-71.

Hao, Yufan. 2013. "Domestic Chinese Influences on U.S.-China Relations." In Tangled Titans: The United States and China, edited by David Shambaugh, 125-148. Lanham, MD: Rowman \& Littlefield.

Hughes, Christopher. 2011. "Reclassifying Chinese Nationalism: The Geopolitik Turn.” Journal of Contemporary China 20 587 (71): 601-620.

Kleinsteiber, Meghan. 2013. "Nationalism and Domestic Politics as Drivers of Maritime Conflict." SAIS Review of International Affairs 33 (2): 15-19.

Lautz, Terry. 2013. "The Cultural Relationship." In Tangled Titans: The United States and China, edited by David Shambaugh, 211-233. Lanham, MD: Rowman \& Littlefield. 
Nathan, Andrew J., and Robert S. Ross 1997. The Great Wall and the Empty Fortress: China's Search for Security. New York: Norton.

Schell, Orville, and John Delury. 2013. Wealth and Power: China's March to the Twenty-first Century. New York: Random House.

Shaller, Michael. 2015. The United States and China in the Twentieth Century. New York: Oxford University Press.

Shen, Simon. 2004. "Nationalism or Nationalist Foreign Policy? Contemporary Chinese Nationalism and its Role in Shaping Chinese Foreign Policy in Response to the Belgrade Embassy Bombing." Politics 24 (2): 122-130.

Tang, Wenfang, and Benjamin Darr. 2012. "Chinese Nationalism and Its Political and Social Origins." Journal of Contemporary China 21 (77): 811-826.

Tok, Sow Keat. 2010. "Nationalism-On-Demand? When Chinese Sovereignty Goes Online." In Online Chinese Nationalism and China's Bilateral Relations, edited by Simon Shin and Shaun Breslin, 15-17. New York: Lexington Books.

Wang, Zheng. 2012. Never Forget National Humiliation: Historical Memory in Chinese Politics and Foreign Relations. New York: Columbia University Press.

Zedong, Mao. 1966. Quotations from Chairman Mao. Beijing, China: Foreign Languages Press.

Zhao, Suisheng. 2004. Nation-State Construction: Dynamics of Modern Chinese Nationalism. Stanford, CA: Stanford University Press.

Zhao, Suisheng. 2013. "Foreign Policy Implications of Chinese Nationalism Revisited: the strident turn." Journal of Contemporary China 22 (82): 535-553.

Zhimin, Chen. 2005. “Nationalism, Internationalism, and Chinese Foreign Policy.” Journal of Contemporary China 14 (42): 35-53.

Cite this article: Giannakos, S. 2019. Chinese Nationalism: Myths, Reality, and Security Implications. Nationalities Papers 47: 149-161, doi:10.1017/nps.2018.9 